\title{
https://doi.org/10.52240/1857-2367.2020.2(21).16 \\ STUDIUL ANATOMIC COMPARATIV AL FRUNZELOR SPECIEI LYCIUM BARBARUM L.
}

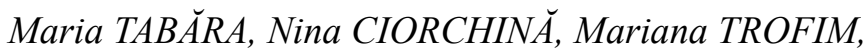 \\ Alina CUTCOVSCHI-MUŞTUC \\ Grădina Botanică Națională (Institut) ,Al. Ciubotaru”, \\ Chișinău, Republica Moldova
}

\begin{abstract}
A study has been carried out on the anatomical structures of the species Lycium barbarum L. and of the goji varieties from the collection of the National Botanical Garden (I) "Alexandru Ciubotaru", grown under the pedo-climatic conditions of the Republic of Moldova. The comparative anatomical study was performed on a complex of anatomical indices: cuticle type, bristles, stomata, calcium oxalate crystals.

Key words: Lycium barbarum L., cultivar, anatomy, leaf blade.
\end{abstract}

Fructele arbuştilor fructiferi constituie o categorie valoroasă de alimente, bogate în compuși naturali cu acțiune adaptogenă și o nutriţie echilibrată. Datorită conținutului de substanțe bilologic active (vitamine, flavonozide, taninuri, acizi organici, fibre alimentare) fructele sunt solicitate tot mai frecvent în calitate de sursă de materie primă pentru industria alimentară, farmaceutică şi cosmetică.

Culturile bacifere se adaptează la condiţiile de viaţă prin diferite căi, iar adaptările structurale (anatomice) au un rol important pentru existenţa lor în condiţii de stres. Schimbările adaptive ale plantelor la factorii de mediu nefavorabili (secetă, îngheț) la nivel structural pot fi analizate cu precizie înaltă pe lamina frunzei, întrucât frunza este cel mai plastic organ al plantei care reacţionează receptiv la schimbările mediului ambiant [1].

Epiderma frunzei, ca ţesut de protecţie şi componentele ei anatomice (celulele stomatice, celulele epidermale propriu-zise, celulele anexe, celulele vecine) au un rol important în procesele de fotosinteză, transpiraţie și respiraţie. Epiderma frunzei mai este şi barieră mecanică şi histochimică în calea pătrunderii agenţilor patogeni în frunză şi plantă. Epiderma serveşte ca filtru efectiv al razelor UV pentru mezofilul asimilator.

Pentru satisfacearea cerințelor crescânde, în ultimii ani amelioratorii crează forme, varietăţi și soiuri noi de goji cu particularități biologice noi, rezistente la secetă și ger, cu calităţi comerciale și gustative înalte. În acest scop, în Laboratorul Embriologie și Biotehnologie al Grădinii Botanice Naţionale (Institut) "Alexandru Ciubotaru" s-a elaborat protocolul de multiplicare in vitro a materialului săditor de calitate înaltă la unele soiuri noi de goji şi a fost înființată colecția de goji.

Scopul lucrării constă în studiul anatomic comparativ al speciei Lycium barbarum L. şi soiurilor noi de goji derivate de la acestea pentru elucidarea indicilor anatomici de identificare și cei cu caracter adaptiv la condițiile pedo-climatice din Republica Moldova.

Soiul 'Erma'. Frunzele acestui soi pe secţiunile transversale și preparatele superficiale ale limbului se disting epidermele superioară și inferioară unistratificate, alcătuite din celule bine împachetate, poligonale, cu pereții externi uşor îngroşaţi. Celulele epidermale sunt acoperite cu un strat de cuticulă care pătrunde ușor printre celule. Pe preparatul superficial al epidermei superioare se observă celule cu pereți celulari ondulați. 
Menționăm prezența stomatelor de tip anomocitic pe ambele epiderme, dar mai multe pe cea inferioară. Mezofilul frunzei este diferențiat dorso-ventral, țesutul palisadic este format din două rânduri de celule uşor alungite, bine aranjate sub epiderma superioară. Epiderma inferioară prezintă celule rotunde sau ovale. Celulele cu druze mari de oxalat de calciu sunt dispersate din abundenţă în limbul frunzei.

Soiul 'Ning Xia N1'. Structura anatomică a frunzei acestui soi se caracterizează prin cuticulă bine reprezentată. Stomatele de tip anomocitic, sunt prezente pe ambele epiderme, fiind înconjurate de 4 celule anexe circulare. Celulele epidermale sunt izodiametrice. Sunt prezente cristale cu oxalat de calciu sub formă de druze.

Specia Lycium barbarum L. (cătina de gard) din flora spontană. Epiderma foliară are celule de contur neregulat. Pereţii celulari sunt moniliformi îngroşaţi. Aparatul stomatic este predominant de tip anomocitic, limbul foliar fiind amfistomatic. Perii tectori (trihomii) sunt absenţi ca şi la cele două soiuri de goji studiate în această lucrare [2].

Mezofilul frunzei la specia Lycium barbarum L. are tendinţa de a fi mai compact împachetat comparativ cu soiurile cultivate 'Ning Xia N1' și 'Erma', cu spații intercelulare relativ mici. Aceşti indici structural anatomici evidenţiaţi pot servi în calitate de indicatori taxonomici. Studiul anatomic comparativ denotă semne distinctive ale indicilor anatomici cantitativi: cuticula mai groasă și epiderma superioară mai proeminentă pentru soiurile din teren față de cele din seră și față de specia spontană, grosimea limbului mai mare la soiurile de cultură față de taxonul spontan, fapt ce reprezintă indicatori cu caracter adaptiv la condițiile de mediu.

Cercetările prezentate au fost realizate în cadrul proiectului Programelor de Stat 2020-2023 (20.80009.7007.19) ,,Introducerea și elaborarea tehnologiilor de multiplicare și cultivare prin tehnici convenționale și culturi in vitro a speciilor de plante lemnoase noi".

\section{BIBLIOGRAFIE}

1. Calalb T., Oroian S., Samirhitan M. The structures Indicatos in Definition of the Chokeberry fruite resistance to enviroment factors during storage. Modern phytomorfology, $2^{\text {nd }}$ Intern. Scien. Conf. on Plant Morphology, Lviv, Vol. 4, 2013, pp. 185-188.

2. Tabăra M., Structura anatomică a laminei frunzei speciei spontane Lycium barbarum L. şi a soiurilor, Akademos - Revistă de știință, inovare, cultură și artă, Nr. 1 (56), 2020, pp. 15 - 20. 